\title{
Soil microbial activity and hairy beggarticks' germination after application of crude glycerin ${ }^{1}$
}

\author{
Matheus Ramos Caixeta ${ }^{2 *}$, Saul Jorge Pinto de Carvalho ${ }^{3}$, Poliana Coste e Colpa ${ }^{3}$, \\ Márcio Donizetti de Andrade ${ }^{4}$,Breno Régis Santos ${ }^{5}$
}

10.1590/0034-737X201764020007

\begin{abstract}
Biodiesel stands out as an alternative for petroleum-based products, but its production generates a large amount of by-products. This study was carried out at the Federal Institute of Education, Science and Technology of South of Minas Gerais, Campus Machado, with the objective of evaluating the impacts of the disposal of crude glycerin on agricultural soil and its microbial activity as well as in plant development. An experiment with a completely randomized design, five treatments, and five replicates was developed in the laboratory to analyze microbial activity. Soil samples of $100 \mathrm{~g}$ were incubated for 36 days with concentrations of crude glycerin, namely: 0; 48.7; 146.1;292.2 $\mathrm{L} \mathrm{ha}^{-1}$. Besides these four treatments, flasks without soil and glycerin have composed one more treatment. During this period, the $\mathrm{CO}_{2}$ volume released in each sample was evaluated 11 times. Another experiment was developed in the laboratory with hairy beggarticks' achenes to evaluate crude glycerin effects on plant development. A randomized complete block design was used in a $4 \times 2$ factorial scheme, with five replicates, the same glycerin concentrations, and two glycerin sources (laboratory and biodiesel plant-unit). Crude glycerin stimulated soil microbial activity for doses of up to $143.83 \mathrm{~L} \mathrm{ha}^{-1}$, being a positive indicative for future studies on its application to agricultural soils. Glycerin applications reduced the hairy beggarticks' root protrusion, even at the lowest doses. Residues have $\mathrm{Na}^{+}$contents that limit their application in agricultural soils.
\end{abstract}

Keywords: biodiesel; salinization; microbial respiration; root protrusion.

\section{RESUMO}

\section{Atividade microbiana do solo e germinação de picão preto após aplicação de glicerina bruta}

O biodiesel se destaca como sendo alternativa para a diminuição do uso de derivados do petróleo, contudo sua produção acarreta em um grande volume de subprodutos gerados. O trabalho foi realizado no Instituto Federal de Educação, Ciência e Tecnologia do Sul de Minas Gerais - campus Machado, com o objetivo de avaliar os impactos da disposição da glicerina bruta em solo agrícola sobre a atividade microbiana e o desenvolvimento vegetal. Para a análise da atividade microbiana, um experimento foi desenvolvido em laboratório, com delineamento inteiramente casualizado, cinco tratamentos e cinco repetições. Amostras de $100 \mathrm{~g}$ de solo foram incubadas por 36 dias com quatro concentrações de glicerina bruta, a saber: 0; 48,7;146,1;292,2 $\mathrm{L} \mathrm{ha}^{-1}$, além da ausência de solo e glicerina. Durante este período, realizaram-se 11 avaliações do volume de $\mathrm{CO}_{2}$ liberado, em cada amostra. Para avaliar os efeitos da glicerina bruta sobre o desenvolvimento vegetal, outro experimento foi desenvolvido em laboratório utilizando aquênios de picão preto. Foi utilizado delineamento em blocos casualizados em esquema fatorial $4 \times 2$, com cinco repetições, as mesmas concentra-

\footnotetext{
Submitted on October $6^{\text {th }}, 2014$ and approved on March $2^{\text {nd }}, 2017$.

${ }^{1}$ This study is part of the first author's dissertation.

${ }^{2}$ Universidade Federal de Alfenas, Programa de Pós-Graduação em Ecologia e Tecnologia Ambiental, Alfenas, Minas Gerais, Brazil. matheuscaixeta@ hotmail.com

Federal Institute of Education, Science and Technology of South of Minas Gerais, Machado, Minas Gerais, Brazil. sjpcarvalho@yahoo.com.br; poliana.colpa@ifsuldeminas.edu.br

${ }^{4}$ Cooperativa Regional de Cafeicultores em Guaxupé Ltda., Guaxupé, Minas Gerias, Brazil. marciod@cooxupe.com.br

5 Universidade Federal de Alfenas, Alfenas, Minas Gerais, Brazil. brenors@yahoo.com.br

*Corresponding author: matheuscaixeta@ hotmail.com
} 
ções de glicerina e duas origens do resíduo (laboratório e usina produtora de biodiesel). Para doses de até 143,83 L ha ${ }^{-1}$, a glicerina bruta estimulou a atividade microbiana do solo, sendo indicativo positivo para estudos futuros em relação a sua aplicação em solos agrícolas. As aplicações de glicerina reduziram a protrusão radicular do picão-preto, mesmo nas menores doses. Os resíduos possuem teores de $\mathrm{Na}^{+}$que limitam sua aplicação em solos agrícolas.

Palavras-chave: biodiesel; salinização; respiração microbiana; protrusão radicular.

\section{INTRODCTION}

There is a growing global demand for cost-effective and environmentally friendly fuels (Sarma et al., 2012). Among these fuels, biodiesel stands out as an alternative for reducing oil derivatives (Silva \& Freitas, 2008). It is estimated that by 2016 the world biodiesel market will achieve the amount of 140 billion liters, i.e., an annual growth of $42 \%$ (Fan et al., 2010). Another estimate is that by 2020 global biodiesel production will be 159 billion liters (OECD/FAO, 2011), which means about 16 billion liters of crude glycerin per year.

Although glycerin has a variety of application, including in food, chemical, and pharmaceutical industries, its demand is small in comparison to the volume produced (Cayuela et al., 2010). Among all destinations, soil is the most likely for such waste. However, soil disposal of organic residues may lead to changes in agroecosystems, among which the microbial community is one of the most sensitive, being, therefore, an indicator of soil quality (Giller et al., 1998).

Glycerol, which is the main component of crude glycerin, has an important physiological function, and is a carbon and energy source, being a cryoprotective and osmoregulatory agent for microorganisms (Arruda et al., 2007). Thus, in view of applying this residue to soils, the possible implications of crude residue on microbial community metabolic activity must be evaluated.

The characterization of microbial activity by measuring the $\mathrm{CO}_{2}$ released from microbial respiration is a positive criterion to evaluate the decomposition of organic residues added to the soil (Stotzky, 1965). Laboratory assessment of $\mathrm{CO}_{2}$ release from the soil with organic waste is a safe method, since it allows evaluations in a controlled environment, in a relatively short time (Cerri et al., 1994).

In addition to the implications on soil microbiota, it is also necessary to evaluate the effects on plant development, that is, the effects of the application on plants (Pires \& Mattiazzo, 2008). From that perspective, the problems caused by the presence of toxic substances are easier to detect during the early stages of plant development (Handreck, 1993). In view of this, hairy beggarticks' achenes (Bidens pilosa L.) should be appointed as bio-indicators.
The B. pilosa species has a short cycle that allows immediate evaluations, as well as anatomical features such as phytomelanin deposition, which protects the pericarp, high trichomatous density, and low stomatal density as barriers to the entry of toxic substances (Santos \& Cury, 2011). This allows evaluating the plant sensitivity to residue application.

This study was developed in order to evaluate the impacts of crude glycerin disposal in agricultural soil on microbial activity and plant development.

\section{MATERIAL AND METHODS}

\section{Characterization of crude glycerin}

The crude glycerin used in the experiment was collected in a unit that produces biodiesel from the homogeneous transesterification of frying oil with methanol, using sodium hydroxide $(\mathrm{NaOH})$ as the catalyst. Three flasks of 20 liters each were collected. Three subsamples from each container were collected for physicochemical characterization.

The residue was analyzed for agronomic interest to determine the macro and micronutrient contents, organic matter, $\mathrm{pH}$, humidity, and electrical conductivity according to the method described by MAPA (2007). Heavy metal contents of $\mathrm{Cd}, \mathrm{Pb}, \mathrm{Ni}, \mathrm{Cr}, \mathrm{Cu}$, and $\mathrm{Zn}$ were analyzed due to their toxic potential, according to Embrapa (2009). Exchangeable $\mathrm{Na}$ and $\mathrm{Na}$ contents were determined for being components of biodiesel production, by means of the following equation:

$S A R=\frac{N a}{\sqrt{\frac{C a+M g}{2}}}$

In which concentrations of $\mathrm{Na}, \mathrm{Ca}$, and $\mathrm{Mg}$ in water were expressed in mmol $_{c} \mathrm{~L}^{-1}$.

Fatty acid esters analysis was carried out using a gas chromatography system. Table 1 shows the residue chemical composition used in the biotest.

In order to compare germination test results, laboratory residue containing only glycerol and catalyst $(\mathrm{NaOH})$ was also produced by conventional reaction means between refined soybean oil, anhydrous ethanol, and sodium 
hydroxide $(\mathrm{NaOH})$. Initially, soda was dissolved in ethanol at room temperature. After full dissolution, the liquid was added to the soybean oil, with catalytic transesterification of triacylglycerol. This process used 3.6 L soybean oil, aiming at a $12 \%$ glycerin residue.

The separation of biodiesel phases was done by washing, by adding water to the initially homogenous liquid. After identified, the phases were kept in a container for one week and later separated into a decantation funnel. The phase of interest (glycerin + ethanol + catalyst) then underwent forced drying at $80^{\circ} \mathrm{C}$ (Ferrari et al., 2005a, b) for four hours to remove the remaining ethanol.

\section{Microbial activity}

This experiment used dystrophic red-yellow Latosol (Embrapa, 2013) of clayey texture, collected at a depth of $0-20 \mathrm{~cm}$, located at the coordinates $21^{\circ} 41^{\prime} 55.26^{\prime \prime}$ South latitude, and 45 53' 29.64" West Greenwich longitude. After sampling, the soil was air and shade dried, ground, sieved (2-mm mesh), and homogenized. Subsequently, soil sampling was performed in triplicate for chemical characterization, according to Raij et al. (2001). Table 2 shows the physicochemical characterization of the soil used.

One hundred grams of soil were weighed and packed in hermetically sealed glass vials of $0.5 \mathrm{~L}$ volume. Basal soil respiration was determined by the quantification of total carbon dioxide $\left(\mathrm{CO}_{2}\right)$ released in the microbial respiration process from the soil conditioned in the vials at $25^{\circ} \mathrm{C}$, during 36 days of incubation. Each sample was incubated in the flasks containing a test tube with $10 \mathrm{~mL}$ $1 \mathrm{M} \mathrm{NaOH}$, to capture the $\mathrm{CO}_{2}$ liberated. After the different incubation periods, the $\mathrm{NaOH}$ tubes were withdrawn and received $10 \mathrm{~mL}$ of $\mathrm{BaCl}_{2}(0.5 \mathrm{M})$, and three drops of phenolphthalein for titration with $0.5 \mathrm{M}$ of standard $\mathrm{HCl}$. Readings were taken at 1, 4, 8, 11, 15, 18, 22, 25, 29, 32, 36 days after incubation started. The $\mathrm{CO}_{2}$ release was calculated according to Stotzky (1965).

The experiment was carried out in a completely randomized design (CRD) with five treatments, namely: three doses of crude glycerin; 48.7; 146.1, and 292.2 L ha1 , in addition to soil without residue application, and vial without soil and residue. Each treatment had five replicates.

A time split-plot design was considered for analysis. Data were analyzed using the F-test in the analysis of variance, followed by the use of polynomial regressions. The F-test of variance analysis was also used in order to evaluate the models significance, and significance of coefficients of the models was verified by Student's ttest. The model was selected by means of the higher coefficient of determination $\left(\mathrm{R}^{2}\right)$. The maximum emission point of microbial $\mathrm{CO}_{2}$ was obtained by equating the first derivative of the second-degree equation to zero.

Table 1: Physicochemical characteristics of the crude glycerin used in this study*

\begin{tabular}{|c|c|c|c|c|c|c|c|c|c|c|c|c|}
\hline \multirow{2}{*}{ pH } & $\mathbf{C}$ & OM & $\mathbf{N t}$ & $\mathbf{P}$ & $\mathbf{K}$ & $\mathbf{C a}$ & Mg & $\mathbf{N a}$ & $\mathbf{S}$ & \multirow{2}{*}{$\mathrm{C} / \mathrm{N}$} & \multirow{2}{*}{$\begin{array}{l}\mathbf{H} \\
\%\end{array}$} & \multirow{2}{*}{$\frac{\text { Dens. }}{\mathrm{g} \mathrm{mL}^{-1}}$} \\
\hline & \multicolumn{3}{|c|}{$\%$} & \multicolumn{6}{|c|}{$\mathrm{g} \mathrm{kg}^{-1}$} & & & \\
\hline 8.71 & 22 & 41.03 & 0.11 & 0.04 & 1.64 & 0.46 & 0.10 & 10.70 & 0.02 & 214.35 & 0.72 & 1.01 \\
\hline $\bar{B}$ & $\mathrm{Cu}$ & Mn & $\mathrm{Zn}$ & Cd & $\mathrm{Cr}$ & $\mathbf{P b}$ & Mo & $\mathbf{N i}$ & Dens. & $\mathbf{C E}$ & Est.M. & \\
\hline \multicolumn{9}{|c|}{$\mathrm{mg} \mathrm{kg}^{-1}$} & $\overline{\mathrm{g} \mathrm{mL}^{-1}}$ & 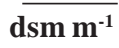 & $\%$ & SAR \\
\hline 1.78 & 0.78 & 1.92 & 1.60 & 0.02 & 0.51 & 0.10 & 0.14 & 0.33 & 1.01 & 8.75 & 35.5 & 37.21 \\
\hline
\end{tabular}

C (carbon), OM (organic matter), Nt (total nitrogen), P (phosphorus), K (potassium), Ca (calcium), Mg (magnesium), Na (sodium), $\mathrm{S}$ (Carbon/nitrogen ratio), H (humidity), Dens.(density), B (boron), Cu (copper), Mn (manganese), Zn (zinc), Cd (cadmium), Cr (chromium), $\mathrm{Pb}$ (lead), Mo (molybdenum), Ni (nickel), EC (electrical conductivity), Est M (methyl ester), SAR (sodium adsorption ratio).

* Averages of the nine sub-samples taken

Table 2: Chemical characterization of the soil used in the experiment

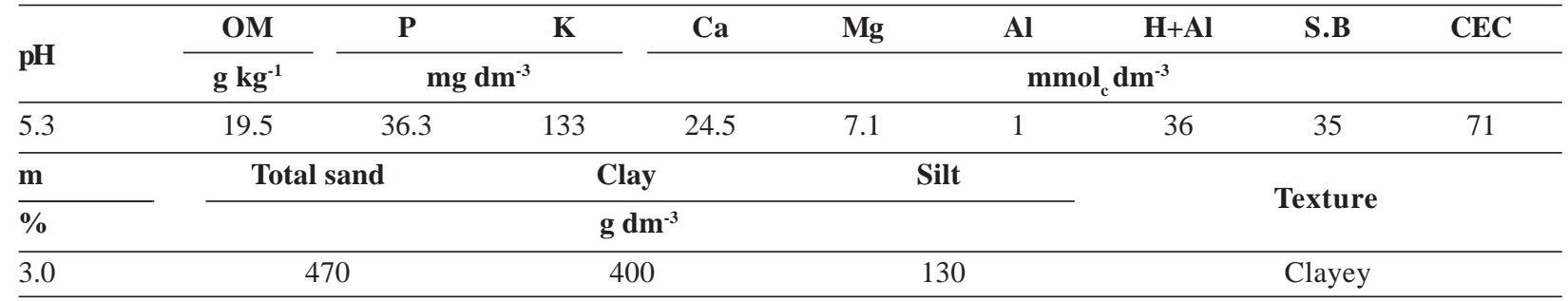

OM (organic matter), $\mathrm{P}$ (phosphorus), $\mathrm{K}$ (potassium), $\mathrm{Ca}$ (calcium), Mg (magnesium), (Aluminum), $\mathrm{H}+\mathrm{Al}$ (hydrogen plus aluminum), SB (base-sum), CEC (cations exchange capacity), $\mathrm{m}$ (saturation in aluminum).

* Average of the three samples analyzed 


\section{Germination}

A sample of 1,000 hairy beggarticks' achenes (B. pilosa) was collected from agricultural and non-agricultural areas within the city of Machado (MG) - Brazil.

Based on the method of Carvalho et al. (2004), germination tests were installed in a germination chamber with constant temperature and humidity control (12 hours of darkness and 12 hours of light at a constant temperature of $25^{\circ} \mathrm{C}$ ).

A randomized block design with five replications was used. A germination chamber shelf characterized each block. Plots were composed of "Gerbox" plastic germination box $(0.11 \times 0.11 \times 0.03 \mathrm{~m})$ containing $50 \mathrm{~B}$. pilosa seeds and two blotting paper sheets. The solution volume applied corresponded to two and a half times the dry paper total mass.

Treatments were organized according to a factorial scheme between two origins of residues (laboratory and biodiesel plant-unit) and four doses of glycerin, namely: 0; 48.7; 146.1 and $292.2 \mathrm{~L} \mathrm{ha}^{-1}$. Each treatment had five replicates.

The number of germinated seeds was counted at 3,5, and 7 days after installation (DAI). Seeds were considered germinated when the protrusion of the radicle through the tegument became visible (Adegas et al., 2003; Carvalho et al., 2004).

The data were analyzed using the F-test in the analysis of variance, followed by the use of the t-test to compare the origin of residues or the use of regressions, whose models were adopted according to data adjustment and biological explanation of their parameters.

\section{RESULTS AND DISCUSSION}

\section{Microbial Activity}

Microbial activity (i.e. $\mathrm{CO}_{2}$ release) increased parabolically with crude glycerin doses, reaching a maximum at 146.1 $\mathrm{L} \mathrm{ha}^{-1}$, as shown in Figure 1A. Moreover, as soil residue dose rose from 0 to $143.83 \mathrm{~L} \mathrm{ha}^{-1}(\mathrm{p}<0.01)$, the microbial activity increased, in terms of $\mathrm{CO}_{2}$ emission. Activity reduced considerably from $143.83 \mathrm{~L} \mathrm{ha}^{-1}$ (maximum) on, evidencing that there are compounds in the residue that are toxic to microorganisms when in high concentrations, such as some salts.

According to Santos et al. (2011), soils with high salt levels may limit the development of plants and microorganisms, thus reducing the microbial population and, consequently, microbiological activity. According to Sardinha et al. (2003), salinization has a strong depressive effect on microbial biomass. It changes markedly the prokaryotic microbial community where most of the microbial biomass is dominated by fungi. In addition, salinization has stronger effects than heavy metal pollution and is probably one of the most stressful environmental conditions for soil microorganisms. Wichern et al. (2006) verified negative impacts on the soil microbiota since the addition of sodium chloride $(\mathrm{NaCl})$ promoted a reduction in basal respiration.

An interaction between the different treatments and the evaluation dates for daily $\mathrm{CO}_{2}$ release was detected. Thus, the analysis was decomposed at each evaluation date (Figures 1 and 2). An increase in microbial activity was observed at the beginning of evaluations, and a respiration peak was reached on the fourth evaluation day, especially with the application of $146.1 \mathrm{~L} \mathrm{ha}^{-1}$ (Figure 1C).

Silva Júnior et al. (2009) found that the addition of organic matter reduces the negative effect of salinity on microbial activity. Wichern et al. (2006) found a reduction in the depressive effect of salinity on the microbiota when they added corn straw (organic material) to the soil. Therefore, soil microorganisms are assumed able to use crude glycerin as a source of carbon for their sustenance and reproduction, increasing soil biomass (Capuani et al., 2012).

However, there was a constant reduction of respiration over time from the fourth evaluation day on (Figures 1D, 1E, $1 \mathrm{~F}$ and 2). According to Capuani et al. (2012), carbon compounds are mineralized, a fact corresponding to the reduction of microbiological respiration. Martines et al. (2006) reported a decrease in respiration after a certain period in soil under influence of the tannery sludge. Silva et al. (2006) also verified higher $\mathrm{CO}_{2}$ emission in the first evaluations, with a subsequent decrease.

Figures $2 \mathrm{E}$ and $2 \mathrm{~F}$ show the second respiration peak that might be related to microorganisms, which died over time since their cells also serve as a substrate for living microorganisms. It occurs because cell walls of the fungi, which are composed of cellulose, chitin, and chitosan, can be degraded. Bacterial cell walls are also used as a substrate (Wagner \& Wolf, 1999).

Even with the high residue C/N ratio, on average 214, microbial activity increased. This is because of glycerol (the main component of crude glycerin) exerts an important physiological function, being a source of carbon and energy, a cryoprotective and osmoregulation agent for microorganisms (Arruda et al., 2007). According to Dillis et al. (1980), glycerol is considered a very low carbon source, absorbable by bacteria and yeasts under both aerobic and anaerobic conditions to obtain metabolic energy and intracellular inorganic phosphate recycling.

Some studies used glycerol as a source of carbon by microorganisms, especially bacteria. Ito et al. (2005) and Papanikolaou et al. (2008), respectively, verified that ethanol and hydrogen could be produced by Enterobacter aerogenes HU-101 and citric acid, and by Yarrowia lypolitica, using crude glycerin from the biodiesel through the fermentation process. 
In order to facilitate the material decomposition, nitrogen may have been immobilized in the soil to attenuate the high $\mathrm{C} / \mathrm{N}$ ratio. In agricultural terms, such immobilization may impair the initial establishment of cultures, but it strongly activates microbial activity (Vargas et al., 2005).

\section{Germination}

There was a reduction in the germination of hairy beggarticks' achenes (root protrusion) in the presence of crude glycerin at all doses, as observed in Figure 3. The nonlinear model $\mathrm{y}=-4.391 \operatorname{Ln}(\mathrm{x})+32.752$ was adjusted to reach $\mathrm{R}^{2}=0.9041$, that is, $90.41 \%$ of the radicular protrusion variability is explained by the model. As the crude glycerin dose is increased to $292.2 \mathrm{~L} \mathrm{ha}^{-1}$, the percentage of hairy beggarticks' achenes germination decreases at a log rate of $4.39(\mathrm{p}<0.05)$.

The t-test verified that there is no difference between the residues (laboratory and biodiesel plant-unit) on plant root protrusion, assuming that the undesirable effects caused by the application are bound to both residues. Through an analysis of crude glycerin chemical composition, it is noteworthy that $\mathrm{Na}^{+}$is the main
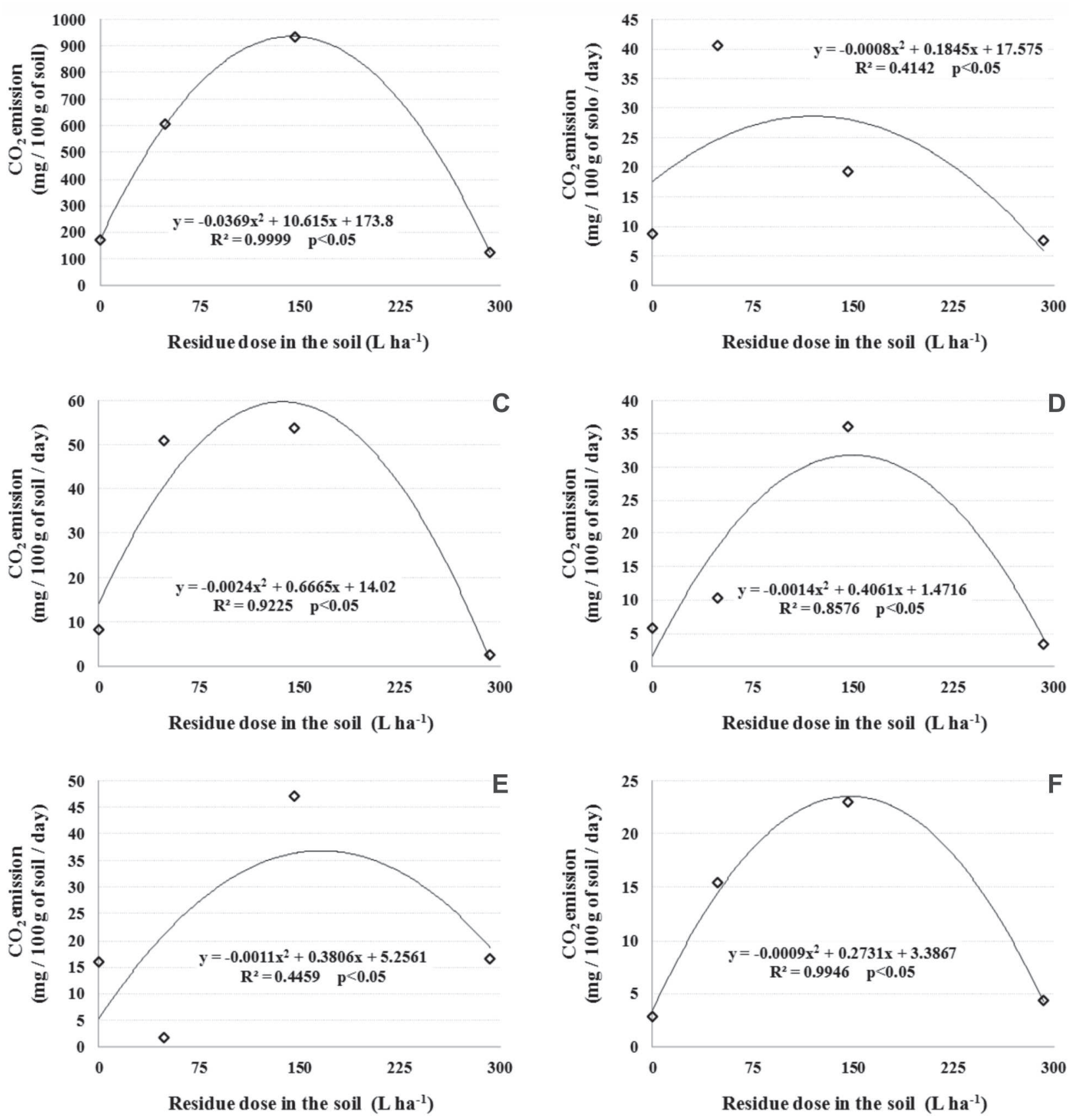

Figure 1: Carbon dioxide release after addition of different doses of biodiesel production residue at different evaluation dates. A Accumulated after 36 days; B - Evaluation after 24 hours; C - Evaluation after four days; D - Evaluation after eight days; E Evaluation after 11 days; F - Evaluation after 15 days. 
component to affect hairy beggarticks' germination negatively. This might happen due to its high contents in crude glycerin, as it is a reaction catalyst.

Some authors observed that salinity negatively affects seed germination. Callegari et al. (2001) found that although lettuce was considered moderately tolerant to salinity, there was a reduction in seed germination, raising the electrical conductivity in the substrate from 3.79 to $10.14 \mathrm{dS} \mathrm{m}^{-1}$. Andréo-Souza et al. (2010) observed germination reduction in jatropha seeds when submitted to saline stress in the imbibition phase. Gordin et al. (2012) concluded that the exposure of Niger seeds to $\mathrm{NaCl}, \mathrm{KCl}$, and $\mathrm{CaCl}_{2}$ reduces the seedlings germinating power and growth.

$\mathrm{Na}^{+}$was the main ion related to saline stress in the present study that contributed to germination percentage decrease. According to Gordin et al. (2012) the imbalance of ions and the toxicity caused by $\mathrm{Na}^{+}$are the main cause of injury of saline stress in the early germination stages. The residue has a sodium content of $10.07 \mathrm{~g} \mathrm{~kg}^{-1}$, i.e., approximately $1 \%$ of its composition. In addition, its electrical conductivity is $8.75 \mathrm{dS} \mathrm{m}^{-1}$, which is high and may impair plant development.
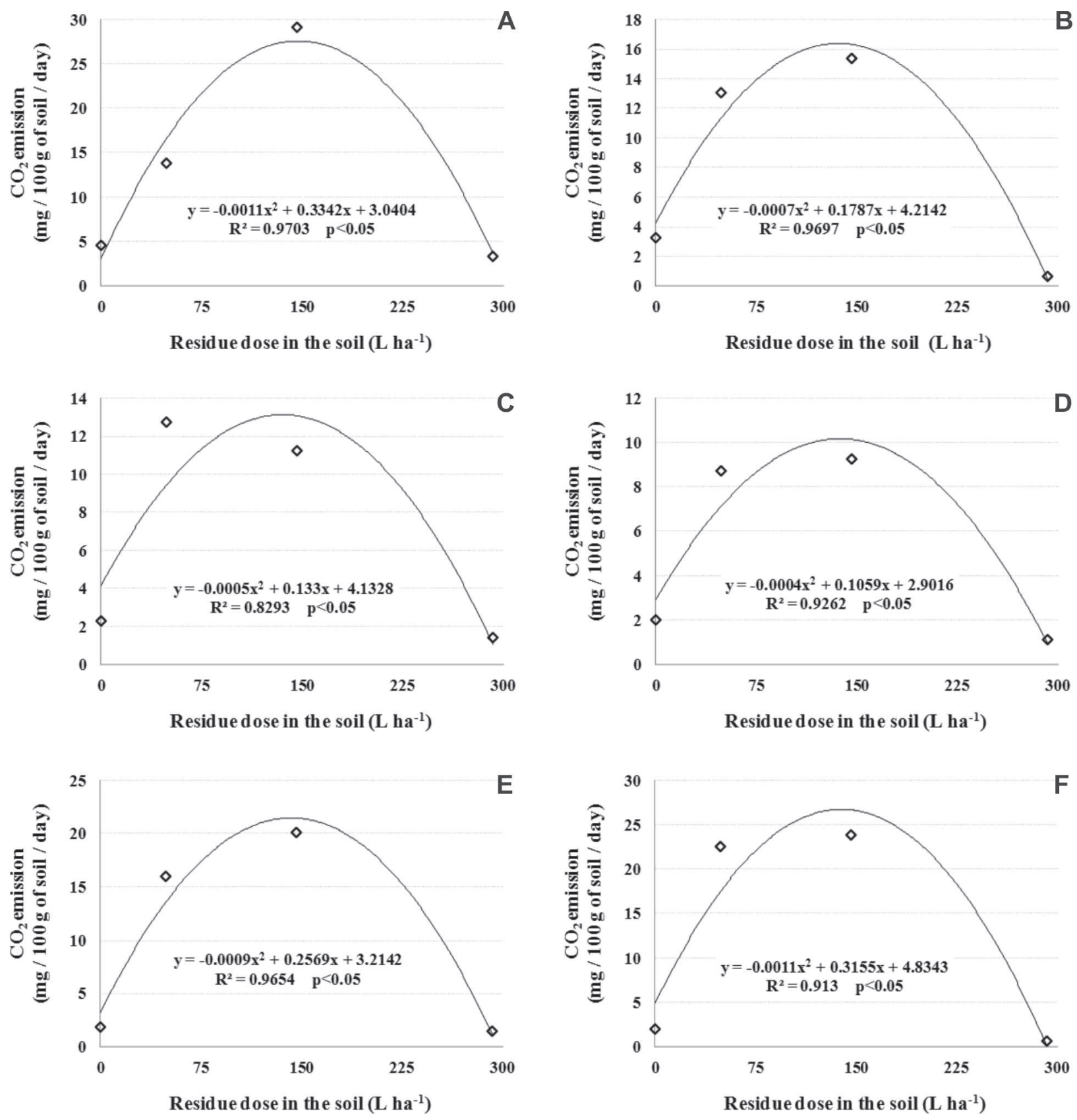

Figure 2: Carbon dioxide release ( $\mathrm{mg} \mathrm{CO}_{2} / 100 \mathrm{~g}$ soil/day) after addition of different doses of biodiesel production residue at different evaluation dates. A - Evaluation after 18 days; B - Evaluation after 22 days; C - Evaluation after 25 days; D - Evaluation after 29 days; E - Evaluation after 32 days; $F$ - Evaluation after 36 days. 
According to Lopes \& Macedo (2008), substrate high salt concentration reduces its water potential, resulting in lower water absorption capacity by seeds, and consequently lower germination capacity. Water availability is a limiting factor for the hairy beggarticks' initial establishment stages, and the substrate water potential decrease resulted in germination reduction.

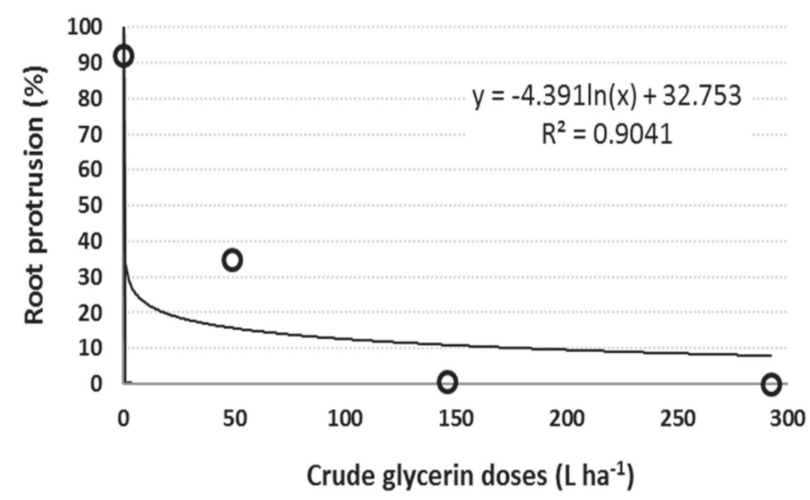

Figure 3: Nonlinear regression model that correlates the crude glycerin doses and the percentage of hairy beggarticks' achenes root protrusion.

\section{CONCLUSIONS}

Crude glycerin promotes an increase in microbial activity, which is a positive indicator for studies on its application in agricultural soils.

The negative effects of salinity can be reduced when microorganisms use the residue organic compounds (glycerin) until a dose of $143.83 \mathrm{~L} \mathrm{ha}^{-1}$.

Crude glycerin applications are detrimental to germination of B. pilosa seeds. This inhibition is observed even at the lowest doses.

Applications of crude glycerin to the soil reduce the root protrusion $B$. pilosa caused mainly by the increase of the medium salinity.

Crude glycerin has $\mathrm{Na}^{+}$contents that can limit its application in agricultural soils, and its soil indexes must be controlled.

\section{ACKNOWLEDGMENT}

The authors would like to thank the Federal Institute of Education, Science and Technology of South of Minas Gerais IFSULDEMINAS, specially campus Machado, for fostering the development of this work.

\section{REFERENCES}

Adegas FS, Voll E \& Prete CEC (2003) Embebição e germinação de sementes de picão-preto (Bidens pilosa L.). Planta Daninha, $21: 21-25$.
Andréo-Souza Y, Pereira AL, Silva FFS, Ribeiro-Reis RC, Evangelista MRV, Castro RD \& Dantas BF (2010) Efeito da salinidade na germinação de sementes e no crescimento inicial de mudas de pinhão-manso. Revista Brasileira de Sementes, $32: 83-92$.

Arruda PV, Rodrigues RCLB \& Felipe MGA (2007) Glicerol: um subproduto com grande capacidade industrial e metabólica. Revista Analytica, 1:56-62.

Capuani S, Rigon JPG, Beltrão NEM de \& Brito Neto JF de (2012) Atividade microbiana em solos, influenciada por resíduos de algodão e torta de mamona. Revista Brasileira de Engenharia Agrícola e Ambiental, 16:1269-1274.

Callegari O, Santos HS \& Scapim CA (2001)Variações do ambiente e de práticas culturais na formação de mudas e na produtividade da alface (Lactuca sativa L. cv. Elisa). Acta Scientiarum, 23:1117-1122.

Carvalho SJP, López-Ovejero RF, Moysés TC, Chamma HMCP \& Christoffoleti PJ (2004) Identificação de biótipos de Bidens spp. resistentes aos inibidores da ALS através de teste germinativo. Planta Daninha, 22:411-417.

Cayuela ML, Oenema O, Kuikman PJ \& Bakker RR (2010) Bioenergy by-products as soil amendments? Implications for carbon sequestration and greenhouse gas emissions. GCB Bioenergy, 2:201-213.

Cerri CC, Andreux F \& Eduardo BP (1994) Incubador para estudos sobre decomposição de material orgânico no solo. Revista Brasileira de Ciência do Solo, 18:01-05.

Dillis SS, Apperson A, Schmidt MR \& Saier MH (1980) Carbohydratetransport in bacteria. Microbiology Reviews, 44:385-418.

Embrapa - Empresa Brasileira de Pesquisa Agropecuária (2009) Manual de análise química dos solos, plantas e fertilizantes. $2^{\mathrm{a}}$ ed. Brasília, Embrapa Informação Tecnológica / Embrapa Solos. $627 \mathrm{p}$.

Embrapa - Empresa Brasileira de Pesquisa Agropecuária (2013) Sistema Brasileiro de Classificação de Solos. $3^{\mathrm{a}}$ ed. Brasília, Embrapa solos. 353p.

Fan X, Burton R \& Zhou Y (2010) Glycerol (byproductof biodiesel production) as a source for fuels and chemicals - Mini Review. Open Fuels Energy Science Journal, 3:17-22.

Ferrari RA, Oliveira VS \& Scabio A (2005a) Biodiesel de soja - taxa de conversão em ésteres etílicos, caracterização físico-química e consumo em gerador de energia. Química Nova, 28:19-23.

Ferrari RA, Oliveira VS \& Scabio A (2005b) Oxidative stability of biodiesel from soybean oil fatty acid ethyl esters. Scientia Agricola, 62:291-195.

Giller KE, Witter E \& Mcgnath SP (1998) Toxicity of heavy metals to microorganisms and microbial processes in agriculture soils: A review. Soil Biology Biochemistry, 30:1389-1414.

Gordin CRB, Marques RF, Masetto TE \& Souza LCF de (2012) Estresse salino na germinação de sementes e desenvolvimento de plântulas de niger (Guizotiaabyssinica (L.f.) Cass.). Acta Botanica Brasilica, 26:966-972.

Handreck K (1993) A. Properties of coir dust, and its use in the formulation of soilless potting media. Communications in Soil Science and Plant Analysis, 24:349-363.

Ito T, Nakashimada Y, Senba K, Matsui T \& Nishio M (2005) Hydrogen and ethanol production from glycerol-containing wastes discharged after biodiesel manufacturing process. Journal of Bioscience and Bioengineering, 100:260-265. 
Lopes JC \& Macedo CMP (2008) Germinação de sementes de couve chinesa sob influência do teor de água, substrato e estresse salino. Revista Brasileira de Sementes, 30:79-85.

MAPA - Ministério da Agricultura, Pecuária e Abastecimento (2007) Manual de métodos analíticos oficiais para fertilizantes minerais, orgânicos, organominerais e corretivos. Brasília, MAPA/ DAS/CGAL. 141p.

Martines AM, Andrade CA \& Cardoso EJB (2006) Mineralização do carbono orgânico em solos tratados com lodo de curtume. Pesquisa Agropecuária Brasileira, 41:1149-1155.

OECD / FAO - Organização para a Cooperação e Desenvolvimento Econômico / Food and Agriculture Organization (2011) Agricultural Outlook 2011-2020. Paris, OECD Publishing. 192p.

Papanikolaou S, Stylianos F, Fick M, Chevalot I, GaliotouPanayotou M, Komaitis M, Marc I \& Aggelis G (2008) Biotechnological valorization of raw glycerol discharged after bio-diesel (fatty acid methyl esters) manufacturing process: Production of 1,3-propanodiol, citric acid and single cell oil Biomass and Bioenergy, 32:60-71.

Pires AMM \& Mattiazzo ME (2008) Avaliação da viabilidade do uso de resíduos na agricultura. Jaguariúna, Embrapa. 9p. (Circular Técnica, 19).

Raij B Van, Andrade JC, Cantarella H \& Quaggio Ja (2001) Análises químicas para avaliação da fertilidade de solos tropicais. Campinas, Instituto Agronômico de Campinas. 285p.

Santos JB \& Cury JP (2011) Picão-preto: uma planta daninha especial em solos tropicais. Planta daninha, 29:1159-1171.

Santos KCF dos, Silva MSL da, Silva LE da, Miranda MA \& Freire MBGS dos (2011) Atividade biológica em solo salino sódio saturado por água sob cultivo de Atriplex numulária. Revista Ciência Agronômica, 42:619-627.
Sardinha M, Muller T, Schmeisky H \& Joergensen RG (2003) Microbial performance in soilsalong a salinity gradiente underacidicconditions. Applied Soil Ecology, 23:237-244.

Sarma SJ, Brar SK, Sydney EB, Bihan YL, Buelna G \& Soccol CR (2012) Microbial hydrogen production by bioconversion of crude glycerol: A review. International Journal of Hydrogen Energy, 37:6473-6490.

Silva GA, Souto JS \& Araújo JL (2006) Atividade microbiana em Luvissolo do semi-árido da Paraíba após a incorporação de resíduos vegetais. Revista Agropecuária Técnica, 27:13-20.

Silva-Júnior JMT da, Tavares RC de, Mendes-Filho PF \& Gomes VFF (2009) Efeitos de níveis de salinidade sobre a atividade microbiana de um Argissolo Amarelo incubado com diferentes adubos orgânicos. Revista Brasileira de Ciências Agrárias, 4:378382.

Silva PRF \& Freitas TFS (2008) Biodiesel: o ônus e o bônus de produzir combustível. Ciência Rural, 38:843-851.

Stotzky G (1965) Microbial respiration. In: Black CA (Ed.) Methods of soil analysis. Madison, American Society of Agronomy p.1551-1572.1Vargas LK, Selbach PA \& Sá ELS (2005) Imobiliza ção

de nitrogênio em solo cultivado com milho em sucessão à aveiapreta nos sistemas plantio direto e convencional. Ciência $\mathrm{Ru}-$ ral, 35:76-83.

Wagner GH \& Wolf DC (1999) Carbon tranformations and soil organic matter formation. In: Sylvia DM, Fuhrmann JJ, Hartel PG \& Zuberer DA (1999) Principles and applications of soil microbiology. Englewood Cliffs, Prentice Hall. p.218-256.

Wichern J, Wichern W \& Joergensen RG (2006) Impact of salinity on soil microbial communities and the decomposition of maize in acidic soils. Geoderma, 137:100-108. 